\title{
咬筋肥大症の一例
}

$\begin{array}{lcc}\text { 三輪 } & \text { 正人・西村 } & \text { 忠郎・八木澤幹夫 } \\ \text { 鈴木 } & \text { 昭男・岡田 } & \text { 貞二・徳田 } \\ \text { 大寿一 } \\ \text { 大岡英太郎・芦原 } & \text { 誠 }\end{array}$

\section{A Case Report of Masseteric Hypertrophy}

\author{
Masato Miwa, Tadao Nishimura, Mikio Yagizawa, \\ Akio Suzuki, Teiji Okada, Hisakazu Tokuda, \\ Eitaro Ohoka and Makoto Ashiwara \\ (Fujita-Gakuen Health University)
}

\begin{abstract}
A 25-year-old man with masseteric hypertrophy is reported. He was operated on by the external approach according to modified Gurney's method.

CT scan was very useful for diagnosing this case. Pathologic examination of the hypertrophied masseter showed normal striated muscle tissue.

Surgical correction of the appearance should be performed if the patient desires esthetic repair. The extraoral approach is recommended because it is easier than the intraoral approach. The cause of masseteric hypertrophy still remains obscure, postoperative care is necessary for a long time.
\end{abstract}

Key words: masseter hypertrophy, work hypertrophy, surgical correction

\section{はじめに}

咬筋肥大症は，片側あるいは両側咬筋の慢性 肥大のため，下顎角部の腫脹を呈する良性疾患 である。本症は，耳下部，煩部あるいは下顎角 部に発生する腫瘍や炎症との鑑別診断が重要 で, 形成外科的治療の対象であある。我々は最 近，片側性咬筋肥大症の一例を経験したので， ここに報告する。

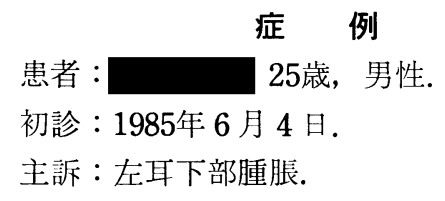

\section{既往歴：特記すべきことなし.}

家族歴：特記すべきことなし。

現病歴：1981年春, 左耳下部の軽度腫脹出 現. 放置していたが，自然に軽快した。1984年 12月より, 再び同部位の腫脹が出現した。発 熱, 疼痛, 口内乾燥感, 開口障害等の自覚症状 はなかった。増大傾向あり，1985年 5 月近医受 診し, 精查目的のため, 当科へ紹介された。

現症：〔全身所見】体格, 策羪は中等度で特 に異常を認めなかった。

〔局所所見】左耳下部に, $6 \times 7 \times 2 \mathrm{~cm}$, 表面平滑, 弾性軟のびまん性の腫溜を認め, 境 


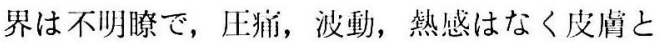
の㦄着もみられなかった（図 1 ）。煩粘膜, Stenon 管開口部および他に頭頸部领域の異常 所見を特に認めなかった。

以上の所胃から，軟部好酸球肉芽腫症あるい は下顎何部の良性腫瘍が疑われたため，精查お よび治療目的のため，入院となった。

入院時検査成績：〔IIIL液所見〕WB C 7600, R B C 551万, Hb 17.6, Pt 23.6万, Ht 51.5, 自液像異常なし，好陖球数 $100 / \mathrm{ml}$, C R P 陰性, R A 陰性, IIIll沈 正常, Ifll清梅毒反応 㓌性, IgG $847 \mathrm{mg} / \mathrm{dl}$, IgA $261 \mathrm{mg} / \mathrm{dl}, \quad$ IgM $181 \mathrm{mg} / \mathrm{dl}, \quad \operatorname{IgE} 160 \mathrm{mg} / \mathrm{dl}$

〔皮内反们〕（即将型）HD， candida 等: 9 程類施行するも全て陰性

（荤延型） P P D 䧔性

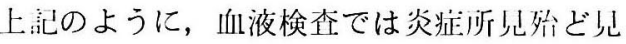
られず，䛉載していないが amylase, aldolase, creatine kinase 等の生化学検笨む特に異常な かった。軟部好酸球肉芽腫症は, 免疫学的検岱 の結果から，否定的である。
耳下腺の资患も疑われたため, 左耳下腺造影 を行った。造影剂の压迫䝪留所思はなかった が, Stenon 管が全体的に偏位しているのが確 認された。また下顎仵部の骨の资出を認めた (図 2 ).

CT撮影したところ，左咬筋の肥大が著明に 認められた。との像は, enhanceにても全く変 化なかった（図 3 ).

これらの検查沂胃から，咬筋の肥大性资忠が

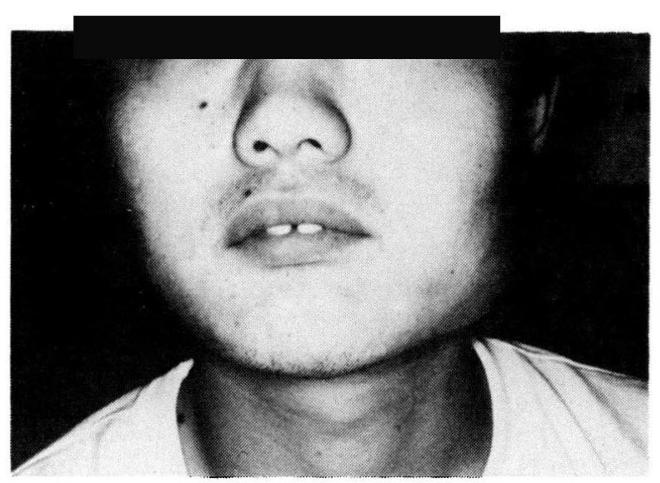

図 I 入院時の顔面写真

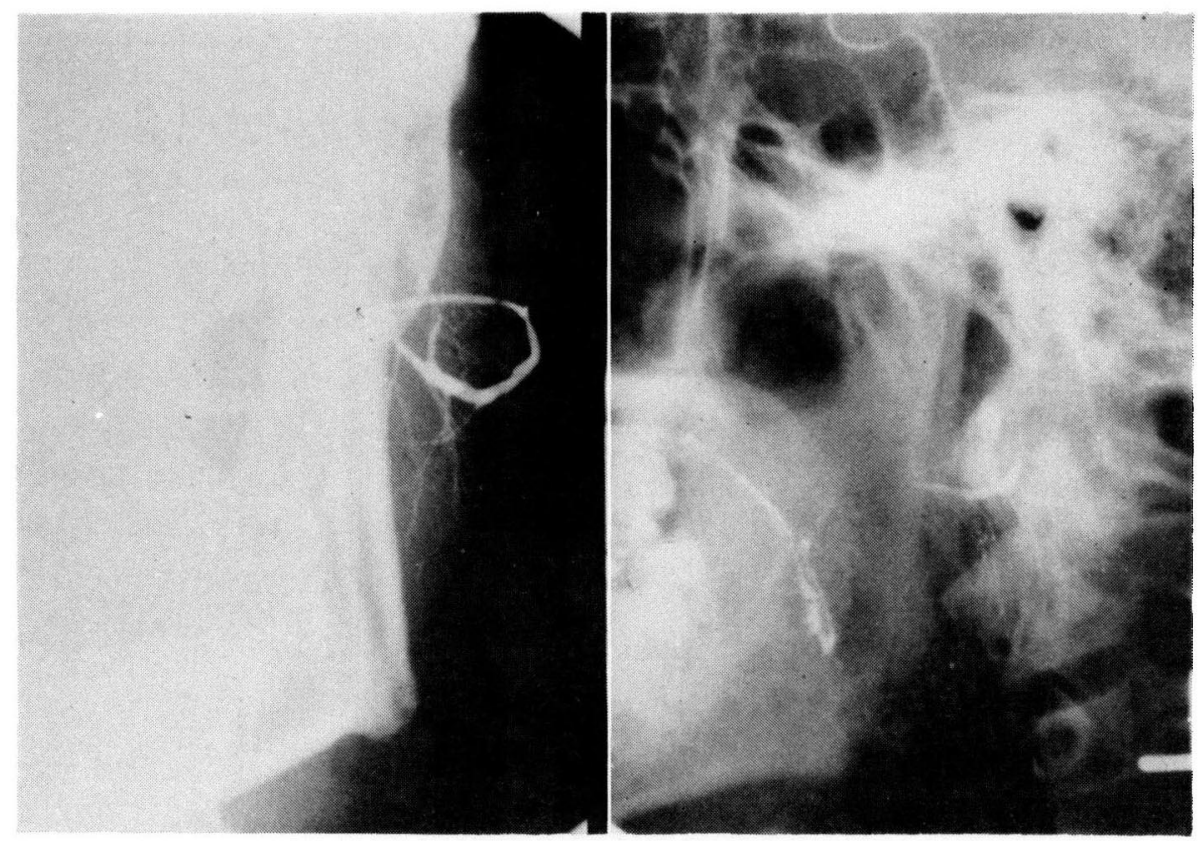

図 2 左耳下腺造影像 
第一に考えられたが，念のため局麻下に open biopsy 㠿施行した。病理組織学的検企の結果 腫脤部位は，図4 にみられるように，全く沙常 な横紋筋組織で占められていることが时らかと なり，荠笳肥大症の確診を得た。

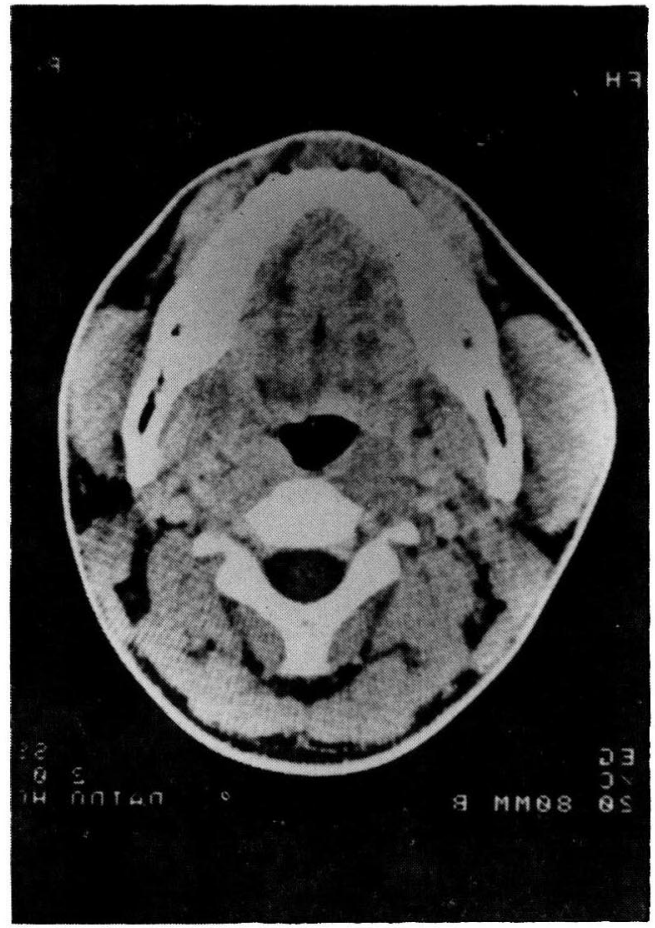

図 3 C T 像

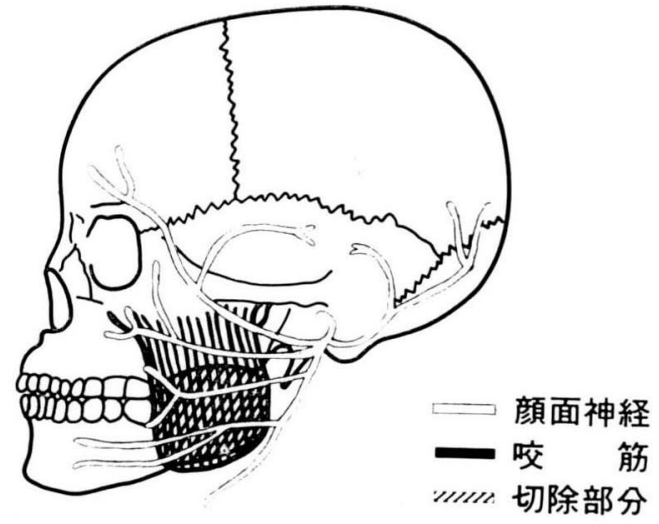

図 5 切除部分の模式図
四 5 の椂なシェーマで示されるように，咬筋 の外倒には顔而神経が走行している，Hilger氏 顔面神経刺激装置を用い, 顔而神経の川腔枝, 下顎枝，頸枝をマークした後，その作置を避的 て全麻下に下顎骨下縁の皮膚に約 $4 \mathrm{~cm}$ の横切開 を扣え，膨隆部の外展を図 5 のように約 $4.5 \mathrm{~g}$ 切除した。

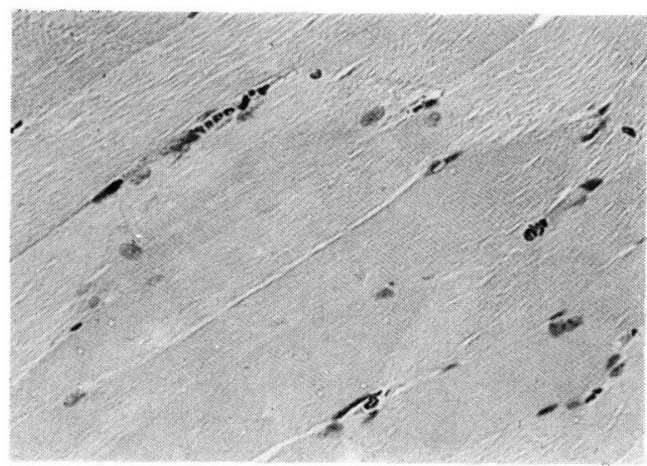

図 4 切除交筋の病理的組織

$$
(\mathrm{H}-\mathrm{E} \text { 染色， } \times 400)
$$

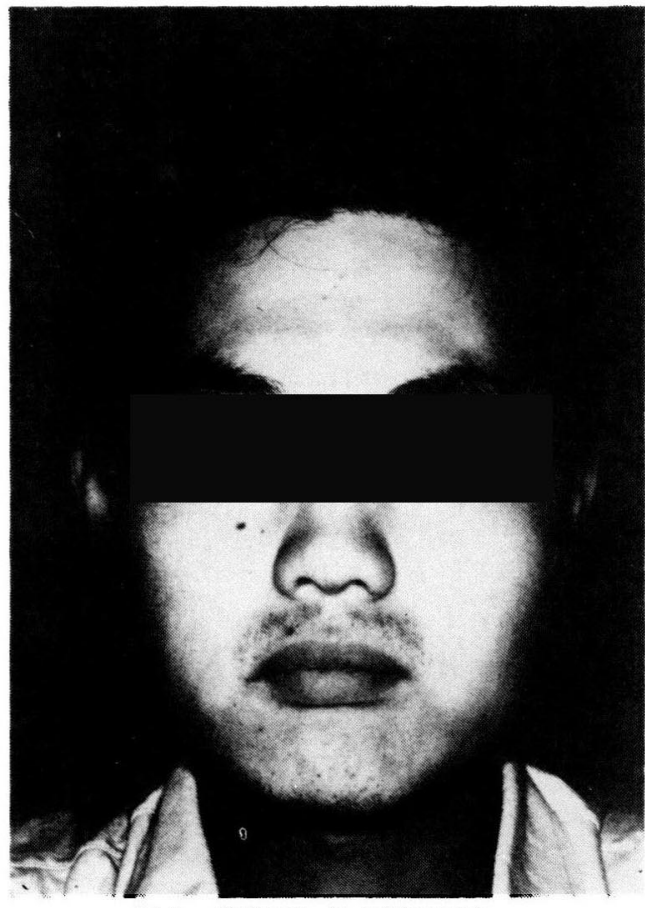

図 6 術後五ケ月の顔面写真 
術後経過は順調で, 退院後も開口障害, 顔面

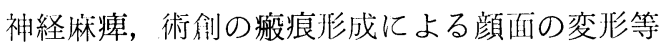
の合併症は全くなく，形成外科的にも应好な結 果を得ている(図6).

\section{考 按}

咬筇肥大症は, 1880年 Legg $^{1)}$ が初めて報告 したとされているが，本邦では，1974年の馬場 ら 2)の報告が最初であり，比較的報告が少ない と思われる，ここで，本症について若干の文献 的考察を行った。

\section{1 ）成因}

咬筋は, 側頭筋, 外側翼突筋, 内側翼突筋之 並んで咀嚼機能を司る筋肉の一つである。乙の ため, 本症の成因として歯のくいしばり, 歯ぎ しり，う歯による片側咬合の兒慣等による咬筋 の作業性肥大説3) が古くより唱えられ，広く受 け入れられてきだ).

しかしながら，この Gurney ら ${ }^{3)}$ の説に対す る反諭屯数多くなされてきている，まず，上記 の椂な特異な咀嚼習慣により本症がひきおてさ れるならば，霜の磨耗が著明にみられることが 予想されるが，実際にはほとんど報告されてい ない ${ }^{5)}$ また，他の咀嚼筋の肥大の合併も期待 されるが，極めて少数の報告をみるのみであ $ろ^{5)}$.

他に顎関節の異常6), 動静脈瘻のごとき支配 血管の異常 ${ }^{7)}$, 下顎角の骨性肥大 ${ }^{5)}$ 等が成因之 してあげられている。

Guggenheim ら ${ }^{99}$ は，本症の咬筋組織の病理 学的検討を行い, 咬筋線維の肥大を証明してい

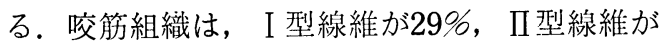
$57 \%$ 占めるとの Ringqvist ${ }^{10)}$ の組織化学的研 究がなされているが，I型線維が優位であると の報告もある ${ }^{11)}$ 。後者によれば，咬筋は側頭筋 之違い, strong, short, and slow acting な I 型線維優位であるため, 高度の作業性肥大を おこしやすいと説明している.

自験例では，下顎角の骨性肥大を認める屯同 様の肥大は正常人で少なからずみられ2)，また 雷ぎしり等の習慣はなく, 成因は不明である.

\section{2 ) 診断}

Oppenheim ら ${ }^{12)}$ は, 本症の trias として咬 筋部の肥大, 耳下腺造影時の Stenon 管の外側 偏位と耳下腺の正常充満像, X線写真上での下 顎角の骨性肥大の証明を挙げている.

また, 池内ら ${ }^{13)}$ は患側の action potential の増大例の存在を指摘している.

自験例では，従来の報告 ${ }^{14) 15)}$ と同様，CTが 本症の診断に非常に有用であった。

\section{3 ）鑑別診断}

本症と鑑別すべき疾患としては, 軟部好酸球 肉芽腫症, 耳下腺腫瘍，血管腫，リンパ管腫， 線維肉腫, 進行性筋ジストロフィー症等の下顎 角部に発生する疾患がある。

軟部好酸球肉芽腫症は, 好酸球増多, III清 $\operatorname{IgE} や \operatorname{IgG}$ 量の増加, アレルギー皮内反応陽 性等の所見があり，本症では容易に鑑別でき た。耳下腺腫瘍む疑ったが, 耳下腺造影時の Stenon 管の外側偏位と耳下腺の正常充満像に より，血管腫は CT enhance で全く変化がな かったことにより鑑別できた。 また，進行性筋 ジストロフィーは，ときに咬筋の仮性肥大をき たすが，血液中の aldolase, creatinine kinase が正常值であったことより除外された。

4) 治療

保存的治療として, 歯のくいしばり, 歯ぎし り，片側咬合の習慣の是正に対する指導も行わ れている ${ }^{5)}$ が, 自験例の様に原因不明の症例で は，患者と十分相談した上で外科的治療にふみ きるのが妥当と思われる。

手術的治療には大別すると, 顔面皮膚からの 切開を行う口外法と煩部粘膜加ら切開を加える 口内法の二種に分けられる。本症に初めて外科 的治療を行った Gurney ${ }^{3)}$ は, 下顎角縁に沿っ た外部切開を加えた後, 腫脹部の筋肉を外層か ら切除した。 また, Adams ${ }^{16)}$ は, 下顎角縁骨 膜から咬筋を剝離し, 内下層の三分の二の筋肉 を切除し，あわせて下顎角の spur を切除する 方法を行っている.

一方，口内法は美容形成に主眼をおいて始め 
られた ${ }^{17)}$ が，十分な視野が得られない所に火点 があり, 我々は Gurney ${ }^{3)}$ の曰外法に従って 手術を施行した。約五ケ月後の現在まで術後経 過は良好であるが，本症の原因が不明である以 上, 術後長期の経過観察が必要であり, この点 に十分留意していく所存である.

$$
\text { まとめ }
$$

25歳男性の片側性の特発性咬筋肥大症一例に 対し，口外法に従って外科的治療を行い，術後 経過良好である症例を経験したので, 若干の文 献的考察を加え報告した。

\section{参考文献}

1) Legg JW : Enlargement of the temporal and masseter muscles on both sides. Trans Pathol Soc (London) 31:361 366, 1880.

2 ) 馬場駿吉, 伊藤博隆: 咬筋肥大症の 1 例. 耳鼻臨 床 $67: 575 \sim 579,1974$ 。

3 ) Gurney CE : Chronic bilateral benign hypertrophy of the masseter muscles. Am J Surg $73: 137 \sim 140,1947$.

4) Riefkohl R, et al : Masseter muscle hypertrophy. An Plast Surg 12:528 532, 1984.

5) Bloem JJAM and Van Hoof RF : Hypertrophy of the masseter muscles. Plast Reconstr Surg $47: 138 \sim 144,1971$.

6) Tempest MN : Simple unilateral hypertrophy of the masseter muscle. Brit J Plast Surg $4: 136 \sim 138,1951$.

7) MacKinnon DM : Hypertrophy of the masseter muscle following submandibular abscesses. Brit J Oral Surg $5: 181 \sim 185$, 1967.
8 ) Masters F, et al: The surgical treatment of benign masseteric hypertrophy. Plast Reconstr Surg 15:215 221, 1955.

9) Guggenheim P and Cohen LB : The histopathology of masseteric hypertrophy. Arch Otolaryng $70: 674 \sim 680,1959$.

10) Ringqvist $M$ : Size and distribution of histochemical fibre types in masseter muscle of adults with different states of occlusion. J Neurol Sci 22 : 429 438, 1974.

11) Arpa J, et al : Hypertrophic branchial muscles. Clinical, electrophysiological and histopathological features in a case. Electromyogr Clin Neurophys 21:569 574, 1981.

12) Oppenheim $H$ and Wing $M$ : Benign hypertrophy of masseter muscle. Arch Otolaryng $70: 207 \sim 210, \quad 1959$

13）池内孝彰，他：咬笳肥大症についての研究. 日口 科誌 19：206〜212, 1970.

14) Braun IF, et al : Computed tomography of benign masseteric hypertrophy. J Comp Ass Tomog $9: 167 \sim 170,1985$.

15）㳕田清己：咬筋肥大症の形成手術. 耳喉 57 : 429 432, 1985.

16) Adams WM : Bilateral hypertrophy of the masseter muscle ; an operation for correction. Brit J Plast Surg $2: 78 \sim 81,1949$.

17) Beckers HL: Masseteric muscle hypertrophy and its intraoral surgical correction. J Max-Fac Surg $5: 28 \sim 35,1977$.

原稿到着：昭和60年 1 月 31 日 別刷請求先：三輪正人

T454 名古屋市中川区尾頭橋 3 丁目 6 番 10 号 保健衛生大学ばんたね病院耳鼻咽喉科 